\title{
EFL Teaching in the Amazon Region of Ecuador: A Focus on Activities and Resources for Teaching Listening and Speaking Skills
}

\author{
Paul F. Gonzalez ${ }^{1}$, Cesar A. Ochoa ${ }^{1}$, Paola A. Cabrera ${ }^{1}$, Luz M. Castillo ${ }^{1}$, Ana L. Quinonez ${ }^{1}$, Lida M. Solano ${ }^{1}$, \\ Franklin O. Espinosa ${ }^{1}$, Eva Ulehlova ${ }^{1} \&$ María O. Arias ${ }^{1}$ \\ ${ }^{1}$ Universidad Técnica Particular de Loja, Ecuador \\ Correspondence: Paul F. Gonzalez, Departamento de Ciencias de la Educación, Universidad Técnica Particular \\ de Loja, Loja, Ecuador. Tel: 593-07-3701444. E-mail: pfgonzalez@utpl.edu.ec
}

Received: May 13, 2015 Accepted: June 26, 2015 Online Published: July 25, 2015

doi:10.5539/elt.v8n8p94 URL: http://dx.doi.org/10.5539/elt.v8n8p94

\begin{abstract}
Research on teaching listening and speaking skills has been conducted at many levels. The purpose of this study was to analyze the current implementation of classroom and extracurricular activities, as well as the use of educational resources for teaching both skills in public senior high schools in the Amazon region of Ecuador, particularly in the towns of Zamora and Yantzaza. The participants included 188 students between the ages of 15 and 18 years, and 10 English teachers in the area. This study was conducted using a mixed-method (quantitative and qualitative) approach. The instruments to collect information were students' and teachers' questionnaires, teacher's interviews, and observation sheets. In addition, the Cambridge English Unlimited Placement Test was applied in order to determine the students' English proficiency level of listening and speaking skills. The findings revealed that the completion of exercises based on a listening passage and dialogues were the most frequent activities used by students to practice listening in the classroom; meanwhile, dialogues and repetition drills were the most frequent activities applied to develop speaking. With respect to extracurricular activities, listening to English music with lyrics, watching videos, discussions, and conversations with native speakers were most frequently suggested for enhancing listening and speaking. Among the resources, audio CDs and textbooks were the most frequent aids to prompt listening and speaking activities.
\end{abstract}

Keywords: classroom activities, educational resources, extracurricular activities, EFL listening and speaking

\section{Introduction}

The development of the four English language skills: speaking, listening, reading, and writing is fundamental for an effective learning of this language; success in the classroom can be achieved by integrating these four skills in language learning, of course, under the supervision of the teacher (Davies \& Pearse, 2000). In the case of listening and speaking skills, oral interaction is important for an effective teaching-learning process.

Listening and speaking skills constitute primordial aspects when learning English, since in our now highly globalized world, proficiency in English allows people to interact. This favors, among others, commercial, cultural, and professional exchange. Regarding the listening skill, Morley (2001) asserts that it is considered as a widely used language skill in normal daily life. In addition, Usó-Juan and Martínez-Flor (2006) state that this skill is a key factor in developing learners' second language communicative ability. With respect to speaking, Oradee (2012) declares that its mastery is essential when learning a foreign language since it is the basic skill for communication. This author also affirms that speaking as well as listening are the most difficult skills to acquire for EFL learners.

Teaching EFL listening and speaking skills involves many elements; three essential ones are classroom activities, extracurricular activities and resources. Regarding classroom activities, Villalobos (2003) mentions that they are important because they make the teaching-learning process more effective and dynamic. Extracurricular activities are also a significant part of education; being as fundamental as classroom activities for the development of skills (Tenhouse, 2003; Eccles, 2003). Likewise, the influence of educational resources on the teaching-learning process is undeniable since they are indispensable elements in building students' motivation and perception about a language (Araya, 2007).

Across Latin America, some limited research about activities and resources for teaching listening and speaking has been conducted. Some studies have been carried out in Colombia; however, in Ecuador there is no evidence of 
scientific research on this topic. Therefore, this study seeks to analyze the current implementation of the aforementioned elements for teaching EFL listening and speaking skills in public high schools in the Amazon region of Ecuador. Additionally, it aims to provide the education community with pertinent recommendations related to activities and resources to improve listening and speaking skills.

\section{Literature Review}

\subsection{Communicative Competence: Listening and Speaking}

Learners not only need to acquire the linguistic but also the pragmatic knowledge of the target language to be able to effectively use it in real-life situations (Hedgcock, 2002). Consequently, to be competent, both linguistically and pragmatically, one needs the exposure and use of the target language; thus, without sufficient exposure, it would not be possible to develop communicative competence (Kasper, 1997).

When acquiring a second or foreign language, the main purpose of the learner is to have proper communicative skills. From the four language skills (reading, writing, listening and speaking), Kurita (2012) claims that listening comprehension is essential in language learning since learners want to understand second language speakers. Additionally, Morley (2001) indicates that listening is considered as the most widely used language skill in normal daily life. Besides, Usó-Juan and Martínez-Flor (2006) state that this skill has been considered as the most difficult one out of the four skills to learn and it plays a key role in developing learners' second language communicative ability.

Concerning the speaking skill, Lightbown and Spada (2006) explain that "speaking in the target language requires more than one mental task at one time like choosing words, pronouncing them, and stringing them together with the appropriate grammatical markers". Moreover, Oradee (2012) remarks that speaking is considered as the most essential skill when learning a foreign language since it is the basic ability for communication. This author also states that speaking as well as listening are the most difficult ones to be acquired by EFL learners.

Given the fact that communicative competence is the goal of a language classroom, instruction needs to point towards all its components: organizational, pragmatic, strategic, and psychomotor. Communicative goals are best achieved by giving due attention to language use and not just usage, to fluency and not just accuracy, to authentic language and contexts, and to students' eventual need to apply classroom learning to previously unrehearsed contexts in the real world (Brown, 2001).

\subsection{Activities and Resources for Teaching Listening and Speaking}

First of all, it is necessary to point out that teaching-learning activities could be implemented in the classroom in order to make the learning process more effective and dynamic. These types of activities must be properly selected in order to encourage students' participation (Villalobos, 2003); classroom activities are also important to get students involved in the learning process (Stepanyan et al., 2009).

Using communicative skills outside the classroom is also important in the learners' language development (Nunan, 1991). For this reason, extracurricular tasks are a significant part of education; indeed, they are as essential as classroom activities for practicing the language skills (Tenhouse, 2003; Eccles, 2003). Additionally, extracurricular activities are connected to learners' autonomy (Gao, 2009), and provide students with opportunities to discover and develop skills by doing exercises for achievement.

Another aspect that has a significant effect on language learning is the use of educational resources. According to Araya (2007), the influence of educational resources on the teaching-learning process cannot be underestimated, so teachers must be aware of their use in the classroom. The author also states that educational resources are essential elements in building students' motivation and perception about a language.

\subsection{Teaching Listening}

Listening, out of the four language skills, has long been considered the most challenging and difficult one by both foreign language teachers and students. Although listening is a challenging skill to achieve, it is a fundamental component of language learning. On average, it is expected to listen twice as much as one speaks, four times more than one reads, and five times more than one writes (Rivers, 1981; Weaver, 1972); therefore, the importance of this skill is undeniable.

In order to teach listening, there are some factors that affect the acquisition of this skill. In this context, Pourhossein and Reza (2011) state that the significance of listening, the study of its teaching theory, and the use of the most advanced listening teaching methods are the most crucial factors.

Regarding teaching methods, Pourhossein and Reza (2011) claim that the communicative approach is the method that teachers should use to meet the needs of the students and obtain as a result efficient English speakers and 
listeners. They state that English must be taught as a tool for communication and that the listening ability must be at the core of teaching practice.

\subsubsection{Activities and Resources}

According to Agustina and Puspawati (as cited in Cahyono \& Widiati, 2009), activities for teaching listening can be divided into three stages: pre-listening, while-listening and post-listening. These authors recommend that the pre-listening stage can be used to introduce new vocabulary. The while-listening activities involve checking prediction, guessing meaning, filling out forms, making lists, writing down examples, using concept maps, and working with photographs; for this step, Harmer (2007) recommends activities such as reading aloud, story-telling, interviews, and conversations. Finally, the post-listening activities might include writing and having discussions.

In the teaching of listening skills, Harmer (2007) claims that teachers should apply materials that are available in the classroom or language laboratory (intensive listening) such as various types of texts, stories, and news. The author also recommends students to use cassettes, CDs, radio broadcasts, podcasts, films, videos, among others, as sources they can listen to on their own time outside the language classroom (extensive listening).

\subsection{Teaching Speaking}

Speaking has always been considered an important language skill for language learners because it allows speakers, both to convey a message and to interact with other people (Widiati \& Cahyono, 2006). For this reason, teaching speaking demands the use of different methods and strategies that help learners improve their communication skills.

Regarding methods for teaching speaking, the Communicative Language Teaching (CLT) approach is one of the most commonly used. In this respect, Widiati and Cahyono (2006) state that CLT "values interaction among students in the process of language learning". These authors also claim that CLT emphasizes on classroom activities, which have a central role for enabling students to interact and thus improve their speaking proficiency. In addition, carefully prepared instruction and proper practice are necessary to help EFL students speak fluently because they are not usually exposed to the target language.

\subsubsection{Activities and Resources}

According to Harmer (2007), some elements should be considered by teachers at the moment of teaching English speaking skills; they involve the students' need to use correct pronunciation and intonation patterns, word and sentence stress, the rhythm of the second language, various genres and situations, and a number of conversational strategies. To tackle the aforementioned elements, the author recommends a variety of activities such as scripts, dialogues, communication games, discussions, prepared talks, among others. These activities make students more dynamic in the learning process, and at the same time, make this process more meaningful and fun.

For teaching speaking, individual or group activities can be used. Individual activities include storytelling, describing things, and public speech, which are usually transactional. On the other hand, group activities involve role-plays, presentations, debates, dialogues, and small group discussions, which are interactional (Widiati \& Cahyono, 2006).

With respect to resources for teaching speaking, Cahyono (as cited in Widiati \& Cahyono, 2006) explains that video is a motivating tool when used properly. Furthermore, teachers need to prepare worksheets or handouts (e.g., multiple choice questionnaires, anecdote texts, and lists of contradictory situations) that can be used as materials for discussion. Widiati and Cahyono (2006) suggest the use of magazines, books, and the Internet to complete tasks in the EFL classroom. Additionally, Rachmajanti and Risnadedi (as cited in Widiati \& Cahyono, 2006) emphasize that verbal input can be developed through the use of stories, realia, pictures, and puppets.

To sum up, activities and resources are integral to the development of the teaching-learning process which should be considered when teaching listening and speaking; for this reason, they need to be carefully planned by teachers to enhance learners' spontaneity in the performance of speaking.

\subsection{Previous Studies}

Regarding in-classroom and extracurricular activities, as well as educational resources for teaching listening and speaking skills, some limited research has been carried out; however, most of the studies do not integrate both skills.

In a study conducted by Oradee (2012), three communicative activities were used to develop speaking skills: discussion, problem-solving, and role playing. The participants of the study were 49 grade- 11 students from Thailand. The study consisted of applying eight lesson plans with three different communicative activities to the participants. The results of this study led to the conclusion that the students' English speaking abilities, after using 
the three communicative activities, were significantly improved.

Urrutia and Vega (2010) developed an action research study about the influence of games on the improvement of students' oral production. The participants involved were tenth grade students of a public school located in Colombia. To develop the project, video recordings, teachers' journals and students' questionnaires were applied by the researchers. The results showed that students felt better, freer and more confident when performing games in small groups. Also, collaboration, solidarity and interaction among students were particularly seen during these activities.

Another study by Widiati and Cahyono (2006) reviews the teaching of EFL speaking in an Indonesian context within the broader perspective of ESL/EFL language teaching methodology. Aspects such as problems in the teaching of EFL speaking, activities commonly performed, materials usually used in EFL speaking classes, and assessment of oral English proficiency are discussed. The results show that the problems that Indonesian EFL learners face in developing their speaking performance relate not only to their linguistic and personality factors, but also to the types of classroom tasks provided by the teachers. Additionally, not all of the classroom activities have been designed so as to trigger more spontaneous expressions by students. As for the materials for speaking, they can be prepared either by the students based on specific tasks assigned by the teacher or provided by the teacher alone.

Regarding listening skills, Bahrami (2010) conducted a study on the effects of task types on EFL learners' listening ability. In order to carry out this study, 90 Iranian students were randomly selected. This quasi-experimental study consisted of two task-based tests of listening comprehension and a test of language proficiency. There were three groups of intermediate, upper-intermediate, and advanced students who were given special listening tasks related to labeling, selecting, matching, and filling forms during twenty sessions of the whole term. According to the results, task-based input tends to improve the listening-comprehension skill in EFL students. The three types of tasks not only affected the listening comprehension of the participants and improved it, but also corresponded to the three levels of language proficiency and proved to be suitable for all the participants at all levels.

Another study related to the teaching of listening skills is the one by Mousavi and Iravani (2012), whose purpose was to compare authentic and non-authentic listening materials on the listening comprehension of Iranian EFL students. The sample included 80 ten-semester students (upper-intermediate level) who were divided into two experimental treatment groups. A pre-test and a post-test including authentic and non-authentic listening materials were applied in order to identify their benefits; additionally, special listening tasks were used during twenty sessions (10 weeks, two sessions a week), plus 3 test sessions. In conclusion, the results of this study show that implementing authentic listening materials in the EFL classroom is more beneficial for students' listening comprehension and proficiency than using non-authentic materials.

With respect to how relevant materials are in teaching listening skills, Camacho (2013) carried out a case study on the factors affecting listening skills and their implications for the development of communicative competence at a public university in Colombia. The participants were three English intermediate-level students from the Foreign Language program; data were gathered through non-participant observations and semi-structured interviews. Among the results obtained, it was confirmed that the use of materials such as books, podcasts, online exercises, videos, and songs adapted to students' level, helped learners gain a better understanding and enjoy the activities they were engaged in. The way the teacher used instructional materials during the classes had important implications in the development of listening skills among the participants.

\section{Method}

\subsection{Participants}

The sample for this study was obtained from statistical information provided by the Ecuadorian Ministry of Education related to number of high schools, geographical location, and number of students enrolled in the second year of public senior high schools during the academic year 2013-2014.

The population consisted of a sample of 188 students ( 90 men and 98 women) between the ages of 15 and 18 years, and 10 English teachers of senior high schools in the Amazon Region, particularly in the towns of Zamora and Yantzaza. The population was obtained through random sampling of a universe of 367 students enrolled in public high schools.

\subsection{Materials}

1. A questionnaire concerning teaching of listening and speaking skills was applied to both students and teachers. It included questions related to activities in the classroom and extracurricular activities as well as educational resources. 
2. Interviews about the aforementioned elements that influence the teaching of listening and speaking skills were applied to teachers.

3. The Cambridge English Unlimited Placement Test was administered in order to know the students' English proficiency level of listening and speaking skills based on the Common European Framework (CEFR) levels.

4. Observation sheets were used to gather information from a total of 15 classes in order to obtain further information about the teaching process in the participant high schools. The researchers took notes on the elements related to activities in the classroom and extracurricular activities as well as educational resources that the teachers used. Moreover, data collected were used to attain a clear idea about the teachers' English proficiency level.

\subsection{Procedure}

This study was conducted by using a mixed-method approach, which involves both quantitative and qualitative procedures. A sample of students was randomly selected from public high schools in order to apply questionnaires and interviews. High school English teachers were also randomly chosen to respond a questionnaire and an interview. The positive aspect of random sampling is that the population is given an equal chance of inclusion in the sample without affecting probability (Teddy \& Yu, 2007).

The information gathered was tabulated using Excel software in which the corresponding frequencies and percentages were calculated. The analysis of the quantitative data was conducted by interpreting the results obtained. An important feature of quantitative studies is that they allow researchers to project their results onto a larger population through an objective process (Creswell, 2002; Thorne \& Giesen, 2002). On the other hand, qualitative research involves subjective data that is obtained from the opinions, experiences, and feelings of people (Hancock, Ockleford, \& Windridge, 2009). In the current study, the qualitative analysis was carried out by comparing and contrasting the quantitative results with the information gathered from class observations and interviews.

\section{Results and Discussion}

In this section, classroom and extracurricular activities as well as educational resources for the development of listening and speaking skills were analyzed according to the results obtained after data tabulation. For this analysis, the most relevant percentages (either low or high) were considered and discussed.

It is worth mentioning that teachers believe that their students are not very fond of dealing with listening and speaking. In addition, they think that the English level of their students varies from basic to low-intermediate. This contrasts with the results obtained from the placement tests applied to students, in which $60 \%$ do not even reach a basic level, $33.33 \%$ reach a basic level, and $6.67 \%$ reach a low-intermediate level, according to the CEFR.

\subsection{Activities in the Classroom and Extracurricular Activities}

\subsubsection{Activities in the Classroom}

Based on the students' questionnaire, the most frequent activities used in order to improve listening skills are completion exercises and dialogues (56.91\%), followed by dramatization (18.61\%); while other activities such as listening to music, dictation, and videos had a very low percentage that varied from $1 \%$ to $10 \%$. Similarly, $43.33 \%$ of teachers confirmed that the aforementioned activities are mostly used to develop their students' listening skills and $33.32 \%$ answered that reading aloud and audios also play an important role in the class.

Considering the students' point of view about the frequency of listening activities developed per unit, we found that $78.72 \%$ agreed on the fact that these activities were practiced from three to four times within every unit. When it comes to the teachers' opinion, $80 \%$ confirmed performing listening activities at least three to four times per unit. It can be inferred that students have the opportunity to practice that skill quite frequently during every unit, which implies that students might have a good level of the listening competence.

With respect to the frequency of speaking activities used in each unit, $83 \%$ of students answered that they practice this skill more than three times per unit; this fact has been confirmed by $90 \%$ of teachers. In this context, the most common speaking activities, according to students' opinion, were dialogues $(57.45 \%)$, repetitions $(18 \%)$, and asking questions (11.70\%); furthermore, teachers expressed that dialogues $(32 \%)$ and repetitions $(24 \%)$ are the most frequent speaking activities provided in the classroom.

It is apparent that even though there is not a great variety of activities applied by teachers in order to develop students' listening and speaking skills, it can be stated that there is still a significant choice of a few specific activities that enable the improvement of those skills quite frequently (completion exercises and dialogues for developing listening and speaking respectively). 
Regarding the use of English to perform listening and speaking activities in the classroom, the results show that $94.15 \%$ of the students feel that their teachers emphasize the use of the target language. These results are similar to the ones obtained from the teacher's questionnaire, in which $90 \%$ of them answered that they use English frequently.

The aforementioned results coincide with the class observations, in which the frequent use of English during the listening and speaking activities was confirmed. However, most of the teachers observed did not demonstrate a good command of English; this issue would lead to an incorrect input for their students during the lessons while performing listening and speaking activities. On the other hand, the use of the mother tongue was also observed at certain points of the lesson. The moderate use of the mother tongue (L1) is useful to control the class and to share some cultural matters like jokes; nevertheless, the excessive use of L1 in the EFL classroom can be counter-productive since students would use their mother tongue to communicate among themselves (Sharma, 2006).

Apart from the excessive use of L1 and the poor command of English on the part of teachers, there are other difficulties that might affect the development of listening and speaking skills in the classroom. Students' opinions show that the main difficulties for performing listening activities are speech rate, which represents $39.36 \%$, and pronunciation, which represents $36.17 \%$. Similarly, teachers think that the main problems are speech rate, pronunciation, and vocabulary, with percentages of $53.85 \%, 23.08 \%$, and $23.08 \%$ respectively.

Regarding the most difficult aspect when speaking English, $53.19 \%$ of students consider that pronunciation is the most difficult one. Besides pronunciation, other aspects such as vocabulary and fear of making mistakes were also mentioned. It is significant to observe that $32.45 \%$ of students answered that they are afraid of making mistakes when producing the target language orally. Likewise, teachers think that pronunciation (40\%) and fear of making mistakes (40.67\%) constitute the most difficult aspects learners face when speaking English.

In order to help students overcome their difficulties for listening and speaking English, students mention that the most common strategies that their teachers use to perform the activities in the classroom are repeating the message $(26.60 \%)$ and translating the message into Spanish (25\%); using the dictionary, speaking slowly, and making gestures to convey the message are also other strategies implemented, which represent a total of $40.96 \%$.

On the other hand, $40.91 \%$ of teachers believe that repeating the message constitutes the most useful strategy to help their students deal with problems when listening and speaking English. Making gestures to explain the message is also a strategy employed by teachers $(27.27 \%)$. Finally, using the dictionary, translating the message into Spanish, and speaking slowly are applied by teachers (31.83\%).

\subsubsection{Extracurricular Activities}

In the case of extra-class activities for practicing listening, almost three quarters of students (71.26\%) expressed that the most recommended extracurricular activities were listening to English music with lyrics, watching videos, and talking to native speakers. On the contrary, a small percentage of students $(19.14 \%)$ affirmed that none of the mentioned activities were suggested by teachers. In addition, the results obtained from the teachers' questionnaire are not very different since $88.46 \%$ of their responses coincided with those provided by students.

For practicing speaking, the most recommended by teachers were watching videos at home and discussing them in class $(25.92 \%)$, having conversations with English native speakers (25.92\%), watching news (18.51\%), and using karaoke and Skype (14.81\%); whereas, students expressed that activities such as watching videos and having conversations with English native speakers (43.61\%) were the most encouraged by teachers. On the other hand, some students (24.46\%) mentioned that their teachers did not suggest any extracurricular activities.

It is necessary to keep in mind that since students are learning to communicate, they should be provided with as many opportunities as possible to practice the language. In this respect, Heejong (2008) suggests that the more students are faced with aural input, the better users of the language they become. For this reason, activities in the classroom and extracurricular activities for practicing listening and speaking skills must be an essential component in the EFL teaching-learning process.

\subsection{Educational Resources}

In line with the results, most of the students (60.64\%) and a significant percentage of teachers $(35.71 \%)$ state that the most used resource to teach listening and speaking is the audio $\mathrm{CD}$, which comes with the textbook. The rest of the resources such as CD-ROMs, videos, and the Internet make up a much less significant component of the learning process.

Direct class observations revealed that although teachers and students claim that the resources used in the 
classroom include an audio $\mathrm{CD}$, none of the teachers in the target classes actually used it. Instead, it was observed that the teachers used the textbook by including reading aloud activities to provide listening input; the problem with this activity is that the input that teachers provide is not authentic since some of them do not have a high proficiency level of English.

Moreover, with respect to the level of difficulty of the activities from the textbook, the results of the questionnaires show that the listening activities were moderately easy, as $62.23 \%$ of the students and $50 \%$ of the teachers claimed this fact, while a small percentage of students $(14.36 \%)$ and teachers $(20 \%)$ considered them to be difficult. This means that there was a small subset of students that were having difficulties with the listening activities from the textbook. In this case, it is important to consider the needs of all of the students and look for additional listening activities with a lower level of difficulty. Concerning speaking, a significant percentage of students and teachers, $57.45 \%$ and $50 \%$ respectively, feel that the speaking activities in the textbook are moderately easy. It is also worth mentioning that almost $(20 \%)$ of the students and $(10 \%)$ of teachers consider the speaking activities in the book to be difficult.

Furthermore, the observations showed that there is an excessive focus on the use of the textbook as a primary source of listening and speaking activities. In this regard, Biemer (1992) indicates that teachers need to keep in mind that the textbook is not the only resource they can use in the classroom. In fact, this author also states that the textbook is often the major resource, but there are other materials that teachers may use or adapt so that students feel engaged in developing listening and speaking skills.

In this context, educational technology is one of the resources that makes learning more interesting and can help students save time and increase English practice (Kasapoglu-Akyol, 2010). Additionally, Prapphal (2003) emphasizes that technology is a good way to help students communicate; although, it cannot be a substitute for a good language teacher. All in all, the resources used to teach speaking and listening skills are much more useful if they are accompanied by the pertinent type of activities and an adequate management on the part of teachers, which involves training them to use those tools appropriately by considering factors such as level, age, learning styles, among others.

According to the teachers' interviews, the importance of technological resources is undeniable nowadays; nonetheless, most of the observed institutions lacked technology devices to be used in the classroom. It is important to mention that a few institutions had these resources available, but teachers did not use them to enhance listening and speaking skills.

In this context, there is a variety of materials such as realia, technology, videos, powerpoint presentations, music, and podcasts that teachers can use, besides the textbook; these materials should be selected considering students' needs and interests to develop real communication among learners. Although the textbook can be the most important resource in the classroom, it is necessary to add extra materials that will allow the students to have different perspectives on the contents studied.

\section{Conclusions}

The completion of exercises based on a listening passage and dialogues were the most frequent activities used by students to practice listening. Dramatizations, watching videos, and listening to music were rarely asserted in spite of the fact that these activities were the most recommended by teachers. On the other hand, dialogues and repetition drills were the most frequent activities carried out by students to enhance speaking. Dramatizations, oral presentations, and discussions were occasionally used although teachers stated that they are indispensable to improve this skill.

Although the results of this research showed that there was a frequent use of English in the classroom, the English proficiency of the teachers was not as high as expected, considering the fact that in Ecuador high school teachers should master a B2 proficiency level according to the CEFR.

When speaking English, the most difficult aspects faced by students were pronunciation and fear of making mistakes; meanwhile, when they tried to listen to information in English, pronunciation and speech rate were the most difficult issues. The predominant strategies to help students overcome obstacles at the moment of listening and speaking were repetition of messages, translation of messages into Spanish, and the use of dictionaries.

Listening to English music with lyrics, watching videos, and talking to native speakers were the most recommended extracurricular activities for practicing listening. On the contrary, watching videos at home and discussing them in class, having conversations with English native speakers, watching news, using karaoke and Skype were the activities teachers encouraged the most.

Teachers and students consider that among the resources, audio CDs were the most frequent aids for enhancing 
listening and speaking; CD-ROMs, videos, and the Internet were rarely used in the classroom. However, it was surprising to see that the aforementioned resources were not used in any of the observed classes; instead, listening and speaking activities were mainly based on the textbook.

Even though technological resources are a trend in EFL teaching today, most of the observed institutions lacked technological devices to be used in the classroom; however, it was noticed that a few institutions had technological devices available, but they were not used to enhance listening and speaking skills.

\section{Recommendations}

Teachers need to be involved in continuous training for professional development in order to improve their proficiency level. This will allow them to know and use a big range of activities and to provide the correct input for their students in order to help them develop listening and speaking skills.

Aspects such as pronunciation and speech rate must be considered when planning and teaching listening skills. Regarding the speaking skill, teachers should emphasize on pronunciation drills and encourage students to become more confident on their speaking production regardless of making mistakes.

Authorities ought to provide technological resources required for teachers to enhance listening and speaking skills, so the textbook and audio CDs are not the only resources used in the classroom. In institutions where technological tools are available, teachers should use them more frequently; in fact, there are technological tools that can be used to improve different English language skills; for example, electronic dictionaries, websites, e-mail, chat software (eg. MSN messenger), word processors, video-cameras, TV, radio, web-based projects, online self-tests, and electronic portfolios.

\section{Acknowledgments}

The authors want to take this opportunity to acknowledge Universidad Técnica Particular de Loja authorities for supporting our research work. Likewise, the collaboration of the principals, teachers, and students of the participating institutions is immensely valuable.

\section{References}

Araya, K. (2007). Teaching materials: A critical position about the role they play in the language classroom. Actualidades Investigativas en Educación, 7(3), 1-16. http://dx.doi.org/10.15517/aie.v7i3.9297

Bahrami, M. (2010). The effect of task types on EFL learners' listening ability. Retrieved from http://www.kon.org/urc/v9/bahrami.html

Biemer, L. B. (1992). The textbook controversy: The role of content. In J. G. Herlihy (Ed.), The textbook controversy. Norwood, NJ: Ablex Publishing Corp.

Brown, H. D. (2001). Teaching by principles. An introductory approach to language Pedagogy. White Plains, New York: Pearson Education Company.

Cahyono, B. Y., \& Widiati, U. (2009). The teaching of EFL listening in the Indonesian context: The state of the art. TEFLIN Journal, 20(2), 269-292.

Camacho, M. (2013). Exploring factors affecting listening skills and their implications for the development of the communicative competence: A case study. Opening Writing Doors, 10(2), 77-116.

Creswell, J. W. (2002). Research design: Qualitative, quantitative, and mixed methods approaches. New York. Sage Publications.

Davies, P. M., \& Pearse, E. (2000). Success in English Teaching. Oxford University Press.

Eccles, J. S., Barber, B. L., Stone, M., \& Hunt, J. (2003). Extracurricular activities and adolescent development. Journal of Social Issues, 59(4), 865-889. http://dx.doi.org/10.1046/j.0022-4537.2003.00095.x

Gao, X. (2009). The 'English corner' as an out-of-class learning activity. ELT Journal, 63(1), 60-67. http://dx.doi.org/ 10.1093/elt/ccn013

Hancock, B., Ockleford, E., \& Windridge, K. (2009). An introduction to qualitative research. Sheffield: The NIHR research design service for Yorkshire \& the Humber. Retrieved from http://www.rds-yh.nihr.ac.uk/wp-content/uploads/2013/05/5_Introduction-to-qualitative-research-2009.pdf

Harmer, J. (2007). The practice of English Language Teaching (4th ed.). New York: Longman. http://dx.doi.org/10.1093/elt/cen029 
Heejong, Y. (2008). The effect of class size reduction on foreign language learning: A case study 1. Language and Linguistics, 2, 1089-1101. http://dx.doi.org/10.1111/j.1749-818X.2008.00090.x

Hedgcock, J. S. (2002). Facilitating access to communities of practice in language teaching: Toward a socioliterate approach to teacher education. The Modern Language Journal, 86(3), 299-317. http://dx.doi.org/10.1111/1540-4781.00151

Kasapoglu-Akyol, P. (2010). Using educational technology tools to improve language and communication skills of ESL students. Novitas-ROYAL (Research on Youth and Language), 4(2), 225-241. Retrieved from http://www.novitasroyal.org/Vol_4_2/kasapoglu-akyol.pdf

Kasper, G. (1997). Can pragmatic competence be taught? Honolulu: University of Hawaii, Second Language Teaching \& Curriculum Center. Retrieved from http://nflrc.hawaii.edu/NetWorks/NW06/default.html

Kurita, T. (2012). Issues in second language listening comprehension and the pedagogical implications. Accents Asia, 5(1), 30-44. Retrieved from http://www.accentsasia.org/3.html

Lightbown, P. M., \& Spada, N. (2006). How languages are learned. London: Oxford University Press.

Morley, J. (2001). Aural comprehension instruction: Principles and practices. Teaching English as a second or foreign language, 3 , 69-85. $\quad$ Retrieved from http://gaining.educ.msu.edu/resources/files/Teaching\%20listening.Morley\%202001.pdf

Mousavi, S. A., \& Iravani H. (2012). The effect of authentic versus non-authentic aural materials on EFL learners' listening comprehension. English Language and Literature Studies, 2(1), 21-27. http://dx.doi.org/10.5539/ells.v2n1p21

Nunan, D. (1991). Language teaching methodology. London: Prentice Hall.

Oradee, T. (2012). Developing speaking skills using three communicative activities (discussion, problem-solving, and roleplaying). International Journal of Social Science and Humanity, 2(6), 533-535. http://dx.doi.org/10.7763/IJSSH.2012.V2.164

Prapphal, K. (2003). English proficiency of Thai learners and directions of English teaching and learning in Thailand. Journal of English Language Studies, 1(1), 6-12. Retrieved from http://jels.iauctb.ac.ir/

Pourhossein, G., \& Reza, A. (2011). A study of factors affecting EFL learners' English listening comprehension and the strategies for improvement. Journal of Language Teaching and Research, 2(5), 977-988. http://dx.doi.org/10.4304/jltr.2.5.977-988

Rivers, W. M. (1981). Teaching Foreign-Language skills (2nd ed.). Chicago: University of Chicago Press.

Sharma, B. K. (2006). Mother tongue use in English classroom. Journal of NELTA, 11, 1-2.

Stepanyan, K., Mather, R., Jones, H., \& Lusuardi, C. (2009). Student engagement with peer assessment: A review of pedagogical design and technologies. Lecture Notes in Computer Science, 5686, 367-375. http://dx.doi.org/10.1007/978-3-642-03426-8_44

Teddlie, C., \& Yu, F. (2007). Mixed methods sampling: A typology with examples. Journal of Mixed Methods Research, 1, 77-100. http://dx.doi.org/10.1177/23456789062

Tenhouse, A. M. (2003). College extracurricular activities - impact on students, types of extracurricular activities. Encyclopedia of Education. http://education.stateuniversity.com/pages/1855/College-Extracurricular-Activities.html

Thorne, M., \& Giesen, M. (2002). Statistics for the behavioral sciences. New York: McGraw-Hill.

Urrutia, W., \& Vega, E. (2010). Encouraging teenagers to improve speaking skills through games in a Colombian public school. Profile Issues in Teachers' Professional Development, 12(1), 11-31. Retrieved from http://www.scielo.org.co/scielo.php?script=sci_arttext\&pid=S1657-07902010000100002\&lng=en\&tlng=pt

Usó-Juan, E., \& Martínez-Flor, A. (2006). Current trends in the development and teaching of the four language skills. Berlin: Mouton de Gruyte. http://dx.doi.org/10.1515/9783110197778

Villalobos, J. (2003). El docente y actividades de enseñanza/aprendizaje: Algunas consideraciones teóricas y sugerencias prácticas. Educere, 7(22), 170-176. Retrieved from http://www.saber.ula.ve/bitstream/123456789/19790/1/articulo5.pdf

Weaver, C. (1972). Human listening: Process and behavior. New York: Bobbs- Merrill. 
Widiati, U., \& Cahyono, B. Y. (2006). The Teaching of EFL Speaking in the Indonesian Context: The state of the art. Bahasa dan seni, 34(2), 269-292. Retrieved from http://sastra.um.ac.id/wp-content/uploads/2009/10/The-Teaching-of-EFL-Speaking-in-the-Indonesian-Cont ext-The-State-of-the-Art-Utami-Widiati-Bambang-Yudi-Cahyono.pdf

\section{Copyrights}

Copyright for this article is retained by the author(s), with first publication rights granted to the journal.

This is an open-access article distributed under the terms and conditions of the Creative Commons Attribution license (http://creativecommons.org/licenses/by/3.0/). 